\title{
Sciendo
}

\author{
Research Article \\ C 2019 Ibrahim Darwish and Bilal Sayaheen. \\ This is an open access article licensed under the Creative Commons \\ Attribution-NonCommercial-NoDerivs License \\ (http://creativecommons.org/licenses/by-nc-nd/3.0/).
}

\section{Manipulating Titles in Translation}

\section{Ibrahim Darwish}

Department of Translation, Yarmouk University, Jordan

\section{Bilal Sayaheen}

Department of Translation, Yarmouk University, Jordan

Doi: 10.2478/jesr-2019-0042

\begin{abstract}
This study investigates the ways in which book titles are manipulated when translated from English into Arabic. One hundred English book titles from various genres whose Arabic translations are manipulated are meticulously studied and analysed against Viezzi's (2013) model of manipulating translated book titles. The findings show that although Viezzi's model fits literary works and movies better, it can be useful in analysing the translated titles of different books coming from various genres. Statistically, the findings reveal the following descending order of the most manipulated aspects of English-Arabic translated titles: being more/less explicit (35\%), offering different keys to the interpretation of the text (20\%), adding/removing genre information (15\%), presenting different viewpoints (10\%), seducing the target readers (8\%), highlighting different characters' aspects (5\%), adding/removing names of characters (3\%), adding/removing allusions to other works (3\%) and suggesting/removing moral lessons $(1 \%)$. It is argued that no matter what aspects of translated titles are manipulated, the whole process is done to attract the potential readers in the target market and this involves multiple players, such as translators, editors and publishers.
\end{abstract}

Keywords: titles, translation, manipulation, English, Arabic

\section{Introduction}

The etymology of the noun 'title' comes from Latin 'titulus' which means 'inscription' (Oxford Online); therefore, by and large a 'title' is that "wording inscribed above the text" (Ferry, 1997, p. 1). Essentially, titles are written to prepare the readers for the content of the text and thus lessen the cognitive processing needed to understand the text quickly and economically (Jovanovic, 1990). Perhaps this is why Arabic has a widespread proverb that reads "What is written is read by its title" (see Farghal \& Bazzi, 2017). This does not only apply to titles of books and other works of art, but also the titles of book chapters and academic articles. In this respect, Rakusan (2016) emphasises that titles are "the most important part of any publication. Although they consist of short strings of words, or even of one word only, they may determine the whole fate of an article" (p. 58). Levin (1977) strongly believes that titles cannot stand by themselves as an independent literary genre; as they are "meaningless without the work [they stand] for, but that there are many kinds of titles and various ways of composing or finding or using them. All of them serve to link a text with its audience" (p. xxxv). In view of that, some scholars (see Genette, 1988) believe that authors put forward the titles of their works prior to the actual writing process, i.e., they start with the title then they proceed to writing the text. On the other hand, others (see Taha, 2009) believe that authors 
write the titles after they have finished writing their texts. However, many other players are often involved in the publications of various text types, such as editors, publishers and social norms. In other words, whether written at the very start or at the very end of the writing process, titles might undergo partial or total changes (Gennete, 1988). Adams (1987) is convinced that only 'true titles' are written by the authors themselves without any interference from the other players. At the microlevel, and regardless of who writes the titles and when, they play a crucial role in identifying texts, movies and other forms of art, i.e., titles serve a naming or referring function (see Genette, 1988). At the macro-level, titles have other wider functions, such as informative, phatic, distinctive, descriptive, intertitular, suggestive, seductive, poetic and expressive (see Viezzi, 2013).

\subsection{Translating Titles}

Newmark (1988) summarises the dilemma of translating titles by emphasising that the translated "title should sound attractive, allusive, suggestive, even if it is a proper name, and should usually bear some relation to the original if only for identification" (p. 56). Kelan and Xiang (2006) believe that "translators should keep the characteristics of the original [titles] and consult the cultural backgrounds to keep the informative, aesthetic and commercial functions in balance" (p. 80).

In translating titles, the translator has two principal choices: either to leave the semantic content of the source titles as they are (i.e., literal translation) or to manipulate the translated titles using different methods motivated by various reasons. Some forms of manipulation include: adaptation, transposition, substitution, explications, paraphrase and transliteration (see Viezzi, 2013; Farghal \& Bazzi, 2017). Levin (1977) believes that in translating the title of Wuthering Heights from English into French as Les Hauts de Hurleven the translator did not attempt to translate the English title per se but managed to find a "substitute which conveys both its atmosphere and its onomatopoeia" (p. xxxiv). In so doing, the translator did not translate the source title. In essence, he/she considered the "functions to be performed in another market and in another linguaculture" (Viezzi, 2013, p. 379). In other words, the translator recreated the title in another language, to another market, to be read by new readers with different cultural backgrounds. However, Farghal and Bazzi (2017) believe that when all constituents of a title are proper names, this title is often transliterated into the target language.

Interestingly, Marti and Zapter (1993) argue that a "faithful, literal translation is preferable if it works in the target language, that is, if it is as shocking or conveys the same connotations as the original title. But this is not always possible" (p. 81). In other words, they contend that literal translation should be applied in translating titles unless there are some linguistic, social, cultural and commercial problems that might restrain it. Lotfollahi and Moinzadeh (2012) examine the translation of 60 Hollywood movie titles from English to Persian, while Shokri (2014) analyses the translation of 64 Persian movie titles to English. The results of both studies show that literal translation is the most frequent strategy used in rendering titles from English to Persian and vice versa. Santaemilia (2000) analyses the procedures used in the translation of 800 movie titles from English into Spanish. The findings also point out that literal translation is the most frequent procedure utilised. Similarly, Gavling (2008) reports that literal translation is the most frequent method used in translating 156 book titles from English into Swedish (43\%) and 47 book titles from Swedish into English (60\%).

As regards the translation of book titles into Arabic, Farghal and Bazzi (2017) contend that this area of research is still a "virgin ground that has not yet received due attention" (p. 119). Their study investigates the translation procedures employed by the translators of 100 titles of English bestsellers. The results show the following descending order of the used procedures: literal translation $(60 \%)$, adaptation $(20 \%)$, use of related words $(12 \%)$, paraphrase $(5 \%)$ and transliteration (3\%). They explain that literal translation best works when the titles are transparent and do not contain any culture-bound or allusive references in the source language. They emphasise that commercial factors should not be ignored when translating titles into Arabic. 


\section{Objectives and Procedures}

Jovanovic (1990) avers that using 'titles' reduces the cognitive processing load on the readers' minds as good titles prepare the readers to the subject matter of the reading material. He argues that some titles can pose a challenge for translators when they attempt to translate them from one language into another. He illustrates by discussing the translation of the titles of two movies from English into Serbo-Croat: Taking off was translated as Svlacenje 'Undressing' and They Shoot Horses, Don't They? was rendered into Serbo-Croat as Konje ubijaju, zar ne? 'They Murder Horses, Don't They?'. He explicates that both translations are inadequate. In the former, 'undressing' is not equivalent to 'taking off' as the movie talks about children leaving their parents' homes. Similarly, in the latter 'murder' is not equivalent to 'shoot' as the movie is about coup de grace. He attributes the failure in capturing the essence of the titles in question to the complexities of the two titles and to the translators' ignorance and use of literal translation without giving enough thought to the relationship between the title and the content. In an investigation of the translation of Quentin Tarantino's movie titles into different languages, Santaemilia and Pardo (2014) propose to depart from the traditional typologies in investigating the translation of titles (i.e., literal translation, transliteration, transposition, etc.) to a wider avenue that treats titles as a "complex (and globalised) rewriting phenomenon that benefits the commercial and ideological interests of the film industry" ( $p$. 214).

In this context, this study intends to explore the manipulation of 100 translated book titles from English into Arabic. It departs from the traditional typology of studying translated titles and focuses on manipulated translated titles both at the linguistic and non-linguistic levels. Specifically, it follows Viezzi's (2013) proposed model for the ways titles are changed when translated. He argues that since translation is done for different markets with diverse linguacultures, book title translation does not merely transfer messages from one language into another, but indicates "choosing a title for a translated product" (p. 379). He avers that the translated titles are often different from the source ones for the "conditions and intentions of [their] creations and reception are different" (p. 379). Thus, he identifies nine aspects in which translated titles may be manipulated: 1) presenting different viewpoints, 2) highlighting different characters' aspects, 3) being more explicit, 4) adding genre information, 5) offering different keys to the interpretation of the text, 6) suggesting moral lessons, 7) adding names of principal characters, 8) adding intertextual or intertitular references (allusions) to other works and 9) seducing the target readers.

In this study, we adopt Viezzi's model with slight modifications. We look into manipulated translated titles in terms of: 1) presenting different viewpoints, 2) highlighting different characters' aspects, 3) being more/less explicit, 4) adding/removing genre information, 5) offering different keys to the interpretation of the text, 6) suggesting/removing moral lessons, 7) adding/removing names of characters, 8) adding/removing allusions to other works and 9) seducing the target readers.

We have compiled a comparative bilingual corpus of 100 English book titles translated into Arabic. The corpus was compiled from Index Translationum, a list of translated books across multiple language pairs. Literally translated titles were ignored and only those titles whose translations contain 'manipulation' were included in the corpus. The corpus is analysed both quantitatively and qualitatively based on Viezzi's (2013) model of manipulating translated book titles.

\section{Results, Analysis and Discussion}

Table 1 displays the frequency and percentage of each of the manipulation areas proposed by Viezzi (2013). All nine ways of manipulation are used which proves that Viezzi's model can be applied to analyse the manipulation in fiction and non-fiction book titles. The manipulation choices do not only involve translators, but also other market players, such as editors, publishers and social norms. No matter what method is used to translate a title, the ultimate goal is not to violate any religious or social norms of the readers and consequently attract them to buy the translated publication. 
Table 1. Frequency and percentages of manipulation areas

\begin{tabular}{|lcc|}
\hline Area & Tokens/Frequency & Percentage \\
\hline Being more/less explicit & 35 & $35 \%$ \\
\hline Offering different keys to the interpretation of the text & 20 & $20 \%$ \\
\hline Adding/removing genre information & 15 & $15 \%$ \\
\hline Presenting different viewpoints & 10 & $10 \%$ \\
\hline Seducing the target readers & 8 & $8 \%$ \\
\hline Highlighting different characters' aspects & 5 & $5 \%$ \\
\hline Adding/removing names of characters & 3 & $3 \%$ \\
\hline Adding/removing allusions to other works & 3 & $3 \%$ \\
\hline Suggesting/removing moral lessons & 1 & $1 \%$ \\
\hline \hline Total & $\mathbf{1 0 0}$ & $\mathbf{1 0 0} \%$ \\
\hline
\end{tabular}

\subsection{Being more/less explicit}

Out of the nine ways which translators may manipulate target titles, the highest percentage (35\%) goes to 'being more/less explicit'. Translators may choose to turn a source title that is opaque or metaphorical into a more explicit target title. This decision can be a personal choice or according to the guidelines set by the publisher. To illustrate, Isaac Asimov's The Chemicals of Life was published in Arabic as Sanāșir al-ḥayā: al-inzīmāt, al-fitāmīnāt, al-hormōnāt 'elements of life: enzymes, vitamins and hormones': the source title is less explicit and more metaphorical than the target one. Interestingly, translators may sometimes choose the opposite, i.e., making the target title more implicit. For example, Robert Jordan's Multinational Co-operation: Economic, Social and Scientific Development was published in Arabic as al-munaợamāt al-dawliyya al-mutaxașșișșa 'specialised international organizations': the translated title is more general and opaque as the detailed information in the source title 'Economic, Social and Scientific Development' is reduced to 'Specialised'. In such cases, we believe that other secondary strategies are at play too, i.e., the motivation behind making a target title more or less explicit might be related to the complexities of the markets the target publications are sold in, i.e., some titles might attract the target readers if they are coded and others if they are decoded.

\subsection{Offering different keys to the interpretation of the text}

The second most frequent area of manipulation (19\%) is 'offering different keys to the interpretation of the text'. In other words, translators may decide to lead the target readers towards a different direction from that of the source readers. A case in point is B. F. Skinner's Beyond Freedom and Dignity which was published in Arabic as tiknolōjya al-sulūk al-insāni 'technology of human behaviour': where the main premise of the source title is to lead the readers towards a revision of the out-dated notions of freedom and dignity, the target title seems to lead the reader towards another direction that is more generic. Another example is Humpstone and Taylor's The Restoration of the Earth which was translated into Arabic as al-insān wal xațar 'human and danger': obviously, the direction that the source title is taking the reader is different from that of the target title. The translator's decision to change the direction of the interpretation of the target publication may be related to the translator's own understanding of the text or to market pressure.

\subsection{Adding/removing genre information}

Manipulations related to genre information in the rendered titles claim $14 \%$ of the data. In this method, translators add genre information to the target title that does not exist in the source title. According to Nord (1994), genre information in the source title is sometimes embedded in the author's name. In other words, when the writer is famous in the source language, readers can infer the genre information when they read the name of the author without the need to include this in the source title. Conversely, when the source author is not famous in the target culture, translators 
might opt for adding genre information to the rendered titles. To illustrate, Frederick Meyer's Samuel the Prophet does not have explicit genre information, but in the Arabic translation hayāt Șāmwēl al-nabi 'the biography of Samuel the prophet', the translator added the word 'biography' to make the target reader aware of the genre. In another extreme example, the English title Islam Our Choice was translated into Arabic as limāđa aslamna? majmū̧at maqālāt linuxba min rijāl al-fikr fi muxtalaf al-aqțār San sabab istināqihim al-Islam 'why did we convert to Islam? a collection of articles by a number of intellectuals in various countries on the reason for their conversion to Islam'. Here, the translator decided to lengthen and stretch out the target title to include additional information about the genre (a collection of articles), authors (a number of intellectuals) and content of the book (the reason for their conversion to Islam). The rationale behind such a choice of a lengthy title is very hard to figure out and seems to be complicated. However, we can conjecture that many factors are involved, such as making the title more explicit and attracting the target Muslim readers via adding genre and other types of information. Indeed, the idea of a number of intellectuals converting to Islam is appealing to Arab-Muslim readers who are the prospective buyers of the publication.

\subsection{Presenting different viewpoints}

Changing the point of view of the title accounts for $10 \%$ of the corpus. The point of view of the target title may be changed by translators: a neutral third-person point of view might be changed into a personal first-person and vice versa. By way of example, Harper Lee's To Kill a Mocking Bird was published in Arabic as lā taqtul Sușfür sāxir 'don't kill a mocking bird!': the translator changed the neutral third-person point of view of the source title and addressed the target reader directly in a more personal second-person point of view. Perhaps, the effect of this manipulation is to involve the target readers more in the title, and consequently attract them to buy the translated book. Lastly, while this technique fits fictional publications more than non-fictional ones, it is occasionally used in all written genres.

\subsection{Seducing the target readers}

While this aspect can basically be a by-product of using other methods of title manipulation as we discussed above, it sometimes can be the main player. The ultimate goal of seducing the target readers via manipulating the title of the source publication is to make them interested and consequently buy it. In the corpus, $8 \%$ of the manipulated titles emphasise the "seductive aspect resorting to the usual tools" (Viezzi, 2013, p. 381). In Bertrand Russell's Marriage and Morals, the translator added the word 'sex' to the Arabic title al-zawāj wa axlāqiyyāt al-jins 'marriage and the morals of sex'. By so doing the target reads are seduced by one of the so-called 'usual tools', i.e., sex. Although most Arab countries have witnessed various changes and development at different levels, topics, such as sex, religion and politics are still considered taboo and can still create excitement for the Arab book buyer. Similarly, Alice and Robert Fryling's A Handbook for Engaged Couples was given the Arabic title al-xițba wa šahr al-Sasal 'engagement and the honeymoon': the translator removed the genre information (Handbook) and added the seductive word 'honeymoon' creating a mystique around the new title.

\subsection{Highlighting different characters' aspects}

The focus on certain aspects of the characters is sometimes shifted in the target title for various reasons. This aspect accounts for $5 \%$ of the manipulated titles in the corpus. To illustrate, while the focus in Maria Gleit's Child of China is on a genderless 'child', the focus in the Arabic title ibnat alȘin 'daughter of China' is on a female child, a daughter. This is triggered by the nature of the Arabic grammar that marks gender on words like 'child', i.e., in Arabic the word 'child' has two possible equivalents: țifl 'male child' and țifla 'female child'. The choice to change a 'female child' in the source title into a 'daughter' is definitely informed by the content of the source text. Sometimes, more than one aspect is simultaneously manipulated in the target title. For instance, Sara Bryant's 
How to Tell Stories to Children: And Some Stories to Tell was rendered into Arabic under the title al-jinniyyāt al-ৎašr 'the ten genies': the translator removed the genre information highlighting different aspects of some characters in the stories while at the same time attracting the reader into a more mystical reading experience.

\subsection{Adding/removing names of characters}

Only $3 \%$ of the target titles involve the names of the characters. Richard Blackmore's classic Lorna Doone was translated twice into Arabic. In the first translation, it was given a new Arabic title malikat al-wādi 'queen of the valley', but in the second translation, the source title was only transliterated into Arabic. Put differently, the translators of the former version chose to remove the name of the main character and replace it with a description from the plot. Perhaps, they thought that the new title might attract more readers in the target culture. Possibly, using the word malika 'queen' in the target title ushers exotic and mystical atmosphere alluding to alf layla wa layla 'The Arabian nights' that serves as an attraction to the target reader. Moreover, a typical 'queen of the valley' character in the Arabic literature is often associated with rare beauty that is second to none; therefore, it genuinely attracts any prospective readers.

\subsection{Adding/removing allusions to other works}

It is not rare to find allusions to other works in titles. Interestingly, translators may or may not keep the allusions in the target titles. Not only that, they sometimes add allusions in the target titles that do not exist in the source. Only $3 \%$ of the target titles in the corpus involve manipulating allusions in titles. A case in point is Aldous Huxley's Point Counter Point which was translated into Arabic as qawl Salā qawl 'saying on saying'. The translator added allusion to Hassan Karmi's famous BBC Arabic Service programme that ran for more than thirty years. The reason behind such a choice might be related to phonetic similarities between the source and target titles or to content similarities between the source text and the radio programme. In contrast, William Maugham's The Moon and Sixpence which alludes to a phrase that appeared in the Times Literary Supplement in a review of another novel by the author was removed from the Arabic title qalb al-mar?a 'the heart of the woman'. The deletion of the allusion can be understood on the grounds that it would be very hard for the target reader to trace or comprehend it.

\subsection{Suggesting/removing moral lessons}

In the corpus, there is only one instance $(1 \%)$ in which the translator adds a moral lesson to the target title to attract the reader. To illustrate, A. Cressy Morrison's Man Does Not Stand Alone was published in Arabic as al-Silm yaḑu lil ìmān 'science calls for faith': the source title is more metaphorical than the target one since the book is about how modern scientific discoveries point to the existence of God. While the moral lesson in the source title is implicit, the target title makes it explicit in order to attract the target readers.

\section{Conclusion}

Title translation is not a mere linguistic process of transferring meanings/messages from one language into another. It involves various social, ideological and economic (marketing) factors; therefore, a shift from the traditional approach of studying titles is needed. Although Viezzi's (2013) proposed model for studying manipulated translated titles fits literary works and movies better, it has proven to be useful in studying different types of genres. Indeed, translators manipulate all types of genre, especially their titles. This study highlighted the ways that translators may take to manipulate target titles. Manipulations are often motivated by multiple linguistic and non-linguistic reasons. For example, some titles are changed because the grammar of the target language does not permit the structure of the source title. Religious, economic (marketing), political, social and cultural reasons are always unavoidable when it comes to rendering new publications. Overall, 
different agents do play a role in deciding the publishable target titles. In other words, publishers and translators do not need to gamble with a risky target title that violates any religious, political and social norms in the receiving culture that might result in censoring it.

\section{References}

Adams, H. (1987). Titles, titling, and entitlement. Journal of Aesthetics and Art Criticism, 46, 7-21.

Crown, A. (Producer) \& Forman, N. (Director). (1971). Taking off [Motion Picture]. USA: Universal Picture.

Farghal, M. \& Bazzi, H. (2017). Translation of English fiction titles into Arabic. Translation \& Interpreting, 9(2), $114-137$.

Ferry, A. (1996). The title of the poem. Stanford: Stanford University Press.

Gavling, A. (2008). The art of translation: A study of book titles translated from English into Swedish and from Swedish into English (Unpublished bachelor dissertation). Karlstad University, Karlstad, Sweden.

Genette G. (1988). Structure and functions of the title in literature. (B. Crampe, Trans.) Critical Inquiry, 14 (4), 692-720.

Jovanovic, M. (1990). On translating titles. Babel, 36(4), 213-222.

Kelan, L. \& Xiang W. (2006). On English and Chinese movie title translation. Canadian Social Science, 2(2), 7581.

Levin, H. (1977). The title as a literary genre. The Modern Language Review, 72(4), xxiii-xxxvi.

Lotfollahi, B., \& Moinzadeh, A. (2012). Translation of movie titles from English into Persian: Strategies and effects. Mediterranean Journal of Social Sciences, 3(3), 511-516.

Martí, R. \& Zapter, M. (1993). Translation of titles of films: A critical approach. Sintagma, 5, 81-87.

Nord, C. (1994). Translation as a process of linguistic and cultural adaptation. In E. Dollerup \& A. Lindegaard (Eds.), Teaching translation and interpreting II: Insight, aims, visions (59-67). Amsterdam/Philadelphia: John Benjamins.

Rakusan, K. (2016). The importance of titles. Curr Res Cardiol, 3(3), 58-59.

Shokri, S. (2014). Translating movie titles: Strategies applied on Persian to English cases. Mediterranean Journal of Social Sciences, 5(20), 2568-2573.

Santaemilia, J. (2000). Los títulos de filmes en lengua inglesa y su traducción al español: ¿Un caos intercultural? [The titles of films in English and their translation into Spanish: An intercultural chaos?]. Studies in English Language and Linguistics, 2, 203-218.

Santaemilia, J. \& Pardo, B. (2014). Translating film titles: Quentin Tarantino, on difference and globalisation. Babel, 60(2), 193-215.

Taha, I. (2009). Semiotics of literary titling: Three categories of reference. Applied Semiotics, 22, 43-62.

Viezzi, M. (2013). Titles and translation. University of Trieste. VAKKI-symposium XXXIII 7 (2013) VAKKI Publications 2. Vaasa, 374-384. Retrieved from http://www.vakki.net/publications/2013 NAKKI2013_Viezzi.pdf

Winkler, I. \& Chartoff, R. (Producers) \& Pollack, S. (Director). (1969). They shoot horses, don't they? [Motion Picture]. USA: Anchor Bay Entertainment. 